\title{
On the Ecology of Weeds in the Orchards habitat During Summer Season in Nile Delta, Egypt
}

\author{
Ibrahim A. Mashaly, Sami A. Al-Barati*, Ahmed M. Abd El-Gawad \\ Botany Department, Faculty of Science, Mansoura University, Mansoura, Egypt
}

\begin{abstract}
The present study aims to investigate the ecology of weed communities associated with some orchards habitat using the variations in environmental factors to determine the distribution and abundance of the recognized weed communities in the study areas. The sampled stands were distributed in four Governorates. Field visits were started from January 2014 to September 2015, 45 stands were selected for sampling the vegetation types during summer season. The application of TWINSPAN classification based on the importance values of 49 plant species recorded in selected 45 sampled stands representing the summer orchards sites in the study areas led to the recognition of four vegetation groups (Euphorbia heterophylla, Commelina benghalensis, Cynanchum acutum and Xanthium strumarium were the dominate plants). In summer season, the application of DCA technique proved that, the plant communities recognized by TWINSPAN classification were markedly distinguishable and having clear pattern of segregation on the ordination plane. The application of CCA technique was used to determine the most effective soil variables controlling the abundance and distribution of weed communities associated during summer season.
\end{abstract}

Keywords: Multivariate analysis, Nile Delta, orchards, soil analysis, summer season, weeds.

\section{INTRODUCTION}

Weeds are plants that grow in environments where they are not wanted and in natural landscapes they can outcompete and adversely affect the survival of indigenous flora and fauna (Dwyer and Entwisle, 2016). Habitat destruction is the first threat to biodiversity followed by invasive species (Walker and Steffen, 1997). Weeds as reported by Virtue and Melland (2003), may have significant economic and environmental impacts, it causes biodiversity interference, alteration of ecosystem, movement hindrance, health interference between animal and human and gene interference by hybridization.

Moreover, many harmful effects of weeds on agriculture crops are reported as following: 1) compete with crops, 2) increased the cost of protection, 3) reduce the quality of crops, 4) increased production and processing costs, and 5) decreased the land value. However, weeds have also some useful uses for humans, for example, food, animal feed, medicine, ornamental uses, pollution control, make dye, heating fuel and natural rubber (Zimdahl, 2007).

Just 5\% of Egypt area inhabited with most Egyptian people, where the industries are located and where its food is produced. The production is not enough for a population where $40 \%$ of all food is imported, so the country needs to increase the food production by increasing the cultivated area by reclaiming the dessert which represents the most of the land in Egypt, where is not used (Sarant, 2017). Weed is one of these problems in desert ecosystem as a result of reclamation, where artificial habitats considered as species-rich environments (Wittig, 2002) due to stages immigration of alien species, heterogeneity and disturbances of the habitat (Pysek et al., 2002). Baessler and Klotz (2006) suggest that in the reclaimed areas the human impact is the main reason, which help weedy species to replace the wild plant species. The present study aimed to analyze the plant communities in study areas using multivariate analysis (classifycation and ordination) and determine the soil factors affecting the distribution of the investigated plant communities within the study area.

\section{Study Area}

\section{MATERIAL AND METHODS}

The study area is represented the orchard habitats located in the Nile Delta region. Nile Delta covers a total area of 2.25 million hacters, and it has alluvial soils. The Nile is the main source of water for irrigation, where it is presented mainly on both the east and west sides of the Delta and scattered over different areas in the country (FAO, 2005). The sampled stands were distributed in the three main sectors, Eastern, Central and Western Nile Delta (Figure 1). The average temperature was varied from January to August as following: $13.29-30.97{ }^{\circ} \mathrm{C}, 15.42-28.94{ }^{\circ} \mathrm{C}, 15.09$ $30.02{ }^{\circ} \mathrm{C}$ and $15.42-28.84{ }^{\circ} \mathrm{C}$ for El-Salhia El-Gededa, Port Said, Baltim and Rosetta stations with mean value of $22.59^{\circ} \mathrm{C}, 22.26^{\circ} \mathrm{C}, 22.64^{\circ} \mathrm{C}$ and $22.02^{\circ} \mathrm{C}$, respecttively. The annual relative humidity was varied from $34.29 \%, 60.69 \%, 48.79 \%$ and $56.01 \%$ in May to $57.63 \%$ in December, $67.04 \%$ in November, $65.04 \%$ and $67.28 \%$ in January in the previous stations with mean values of $45.49 \%, 63.90 \%, 56.40 \%$ and 61.66 $\%$, respectively. Precipitation was ranged from 0.04 $\mathrm{mm} /$ day in June in El-Salhia El-Gededa to $1.26 \mathrm{~mm} /$ day in January in Port Said and Baltim stations with mean values of $0.27 \mathrm{~mm} /$ day, $0.408 \mathrm{~mm} /$ day, 0.410 $\mathrm{mm} /$ day and $0.409 \mathrm{~mm} /$ day, respectively.

\section{Soil Analysis}

Soil samples were collected from each stand (triplicates) representing a profile at a depth of 0-30 $\mathrm{cm}$. Soil texture, water holding capacity (WHC), soil porosity, organic carbon and sulphates were determined according to Piper (1947). Calcium carbonate content was determined by titration against 


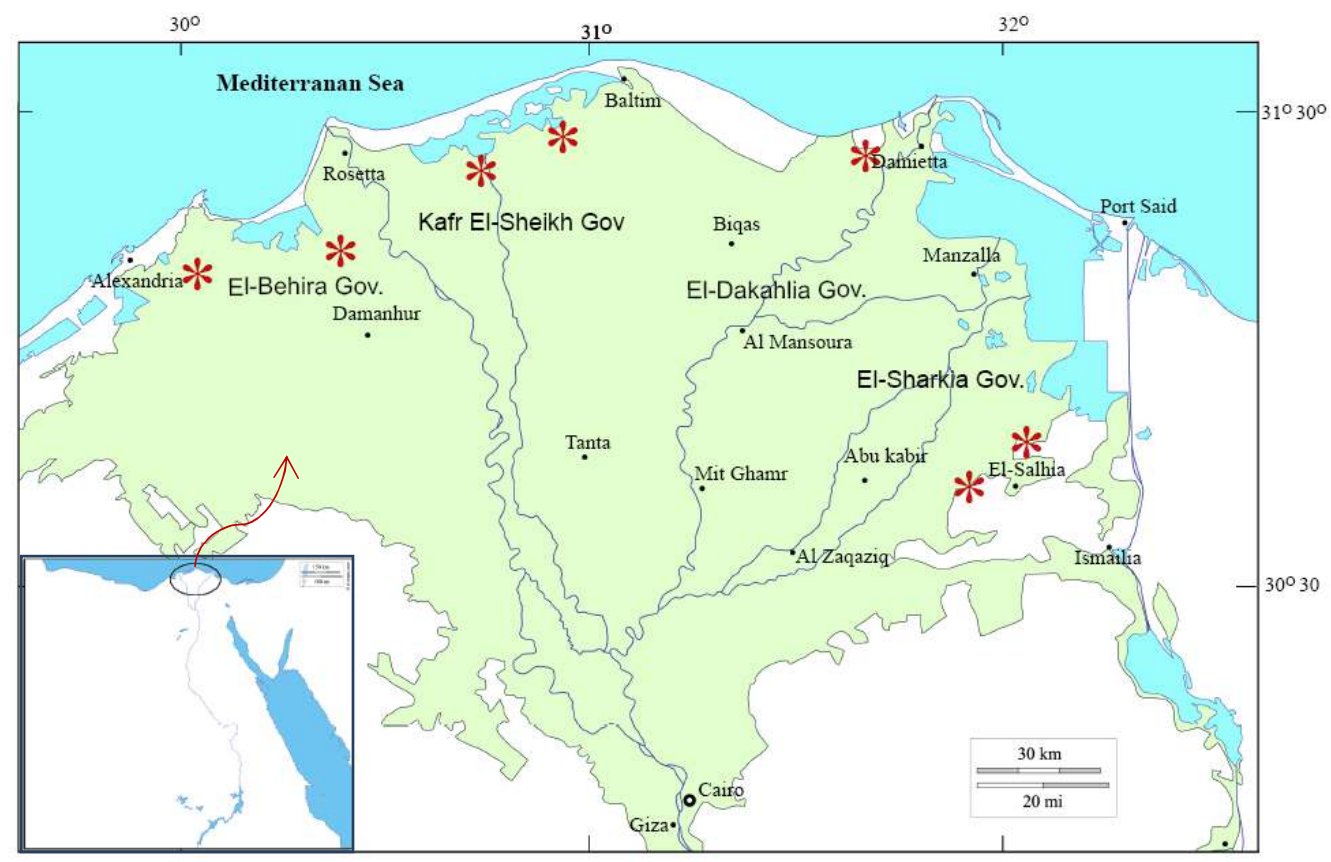

Figure (1): Map of the Nile Delta of Egypt displaying the sampled sites $\left(^{*}\right)$ of the study area.

$1 \mathrm{~N} \mathrm{NaOH}$ and expressed as a percentage according to Jackson (1967). The soil solution (1:5) was prepared for each soil sample. The electrical conductivity, $\mathrm{pH}$ and chlorides were determined by the method adapted by to Jackson (1967). Carbonates and bicarbonates were determined by titration using $0.1 \mathrm{~N} \mathrm{HCl}$ (Pierce et al. 1958). Total dissolved phosphorus was determined by digestion and followed by direct stannous chloride method as described in American Public Health Association (APHA 1998). The total nitrogen was determined by the conventional semi-micro modification of Kjeldahl method (Pirie 1955). The extractable cations $\mathrm{Na}^{+}$and $\mathrm{K}^{+}$contents were determined using Flame Photometer (Model PHF 80 Biologie Spectrophotometer), while $\mathrm{Ca}^{2+}$ and $\mathrm{Mg}^{2+}$ were estimated using atomic absorption spectrometerA Perkin-Elmer, Model 2380.USA (Allen et al. 1974).

\section{Vegetation Analysis}

The sampled stands were distributed in orchards in the Nile Delta region of Egypt; these reclaimed areas are generally cultivated by many fruits such as mango, guava, banana, date palm, citrus, etc. After regular field visits to the various sites of the study area starting from January 2014 to September 2015, 45 stands $(5 \times 5 \mathrm{~m}$ each, according to the minimal area) were selected for sampling the vegetation types in the different orchards of the study.

The mean relative density of the species was calculated from the weeds list and counts according to the fraction of sample stands containing the species (Shukla and Chandel, 1989). The line intercept method is used to determine plant cover as percentage of ground surface (Ellenberg and Mueller-Dombois, 1974). Within every stand, five line intercept transects, randomly placed. The importance value (IV out of 200) was given by the sum values of the relative density and relative cover.

The recorded species were identified according to Täckholm (1974) and Boulos (1999; 2000; 2002; 2005
$\& 2009)$.

TWINSPAN is a hierarchical, polythetic and divisive classification technique (Hill, 1979b; Gauch and Whittaker, 1981 and Hill and Smilauer, 2005), it was carried out by using a computer program CAP, Community Analysis Package, version 1.3.1, (Henderson and Seaby, 1999).However, the ordination techniques applied were the Detrended Correspondence Analysis (DCA) and the Canonical Correspondence Analysis (CCA) using CANOCO (ter Braak 1987). The relationships between vegetation groups and environmental variables (edaphic factor) can be indicated on the ordination diagram produced by Canonical Correspondence Analysis (CCA-biplot), in which points represent plant species and arrows represent environmental variables.

All statistical treatments applied here were according to Snedecor and Cochran (1968) and Anonymous (1993). The data for soil variables in relation to vegetation groups and data for allelopathic potentiality were treated with ANOVA test and separated based on the Least Significant Difference (LSD) at probability level of 0.05 .

\section{Plant diversity measurements}

Plant diversity included the estimation of both species evenness and richness. The simplest diversity measures are number, biomass, cover, or productivity (Krebs, 1985). Two common diversity indices are Simpson's index and the Shannon-Wiener. Both the Simpson's and the Shannon-Wiener indices referred for richness and are non-parametric measures of species heterogeneity that makes no assumption about the normality of species abundance curve (Magurran, 1988).

The following equation is using to calculate the Shannon-Wiener Diversity Index $(\mathrm{H})$ :

$$
H=\sum_{i=1}^{s} P_{i} \ln \left(P_{i}\right)
$$

Where: $P_{i}$ is the number of individuals of species $(s)$ 
$i$ / total number of samples; and $S$ is the numbers of species encountered. While, Shannon-Evenness Index (E) was calculated as following:

$$
E=\frac{H^{\prime}}{\ln _{s}}
$$

Meanwhile, the Simpson's Index (D) was determined according to the following equation:

$$
D=\frac{\sum_{i}\left[n_{i} \times\left(n_{i}-1\right)\right]}{[N \times(N-1)]}
$$

Where, $\mathrm{n}=$ the number of individuals of each different species; $\mathrm{N}=$ the total number of individuals of all the species.

\section{RESULT}

\section{Vegetation Analysis}

a) Classification of stands

The application of TWINSPAN classification, based on the importance values of 49 plant species recorded in 45 sampled stands representing different orchards locations in the study area, led to the recognition of four vegetation communities designated A, B, C, and D
(Figure 2 and Table 1). Community A includes four stands dominated by Euphorbia heterophylla which has the highest importance value of this community $(\mathrm{IV}=82.46)$. The other important and indicator species which attained relatively high importance values in this community type were Setaria verticillata $(\mathrm{IV}=33.92)$, Bidens pilosa (IV=18.28), Cynanchum acutum (IV= 16.41) and Sorghum virgatum (IV=13.34). Community B includes 13 stands dominated by Commelina benghalensis $(\mathrm{IV}=41.86)$. The other important species in this community type were Eleusine indica (IV= 27.14) and Euphorbia heterophylla (IV=24.95). On the other hands, Cenchrus echinatus (IV=15.84) and Dactyloctenium aegyptium ( $\mathrm{IV}=12.86)$ were identified as indicator species in this community type.

Community C comprises 24 stands dominated by Cynanchum acutum (IV=37.07). Portulaca oleracea (IV=33.09), Cynodon dactylon (IV=27.71), Dactyloctenium aegyptium $(\mathrm{IV}=22.95)$ and Bassia indica $(\mathrm{IV}=12.78)$ were the indicator species in this community type. Community D represented by four stands dominated by Xanthium strumarium (IV=70.03). The other important recorded species were Cynodon dactylon (IV=34.82) and Tribulus terrestris $(\mathrm{IV}=30.30)$. However, Cenchrus biflorus (IV=11.30) and Chenopodium album $(\mathrm{IV}=10.77)$ were recorded and identified as an indicator species in this community type.

Table (1): Mean value and coefficient of variation (value in brackets) of the importance values (out of 200) of the recorded species in

\begin{tabular}{|c|c|c|c|c|c|}
\hline No. & Species & Community A & Community B & Community $\mathrm{C}$ & Community D \\
\hline 1 & Alhagi graecorum Boiss. & -- & -- & $1.08(3.73)$ & -- \\
\hline 2 & Amaranthus hybridus $\mathrm{L}$. & -- & -- & -- & $2.07(4.13)$ \\
\hline 3 & Amaranthus graecizans $\mathrm{L}$. & -- & $4.92(10.92)$ & $2.79(6.47)$ & -- \\
\hline 4 & Amaranthus lividus $\mathrm{L}$. & $4.02(8.04)$ & $2.38(8.60)$ & $2.23(5.46)$ & $3.38(6.76)$ \\
\hline 5 & Atriplex semibaccata $\mathrm{R}$. Br. & -- & -- & $1.67(8.33)$ & -- \\
\hline 6 & Bassia indica (Wight) A. J. Scott & -- & -- & $12.78(24.24)$ & $2.33(4.66)$ \\
\hline 7 & Bidens pilosa $\mathrm{L}$. & $18.28(33.33)$ & $8.27(10.51)$ & $3.08(13.67)$ & $2.32(4.64)$ \\
\hline 8 & Boerhavia diffusa $\mathrm{L}$. & $1.40(2.80)$ & -- & $0.22(1.12)$ & -- \\
\hline 9 & Brachiaria eruciformis (Sm.) Griseb. & $12.54(25.08)$ & $9.59(15.02)$ & -- & -- \\
\hline 10 & $\begin{array}{l}\text { Cakile maritima Scop. subsp. aegyptiaca } \\
\text { (Willd) Nyman }\end{array}$ & -- & -- & $0.05(0.26)$ & -- \\
\hline 11 & Cenchrus biflorus Roxb. & -- & $10.55(23.46)$ & $1.00(5.02)$ & $11.30(22.60)$ \\
\hline 12 & Cenchrus echinatus L. & -- & $15.84(28.32)$ & $0.34(1.69)$ & -- \\
\hline 13 & Chenopodium album $\mathrm{L}$. & -- & -- & -- & $10.77(18.08)$ \\
\hline 14 & Chenopodium murale $\mathrm{L}$. & -- & -- & $1.79(4.52)$ & -- \\
\hline 15 & Commelina benghalensis L. & -- & $41.86(66.21)$ & - & -- \\
\hline 16 & Convolvulus arvensis $\mathrm{L}$. & $0.74(1.48)$ & $3.87(13.95)$ & $0.51(2.06)$ & -- \\
\hline 17 & Conyza bonariensis (L.) Cronquist & $3.04(6.09)$ & $9.69(27.05)$ & $1.81(4.92)$ & -- \\
\hline 18 & Corchorus olitorius $\mathrm{L}$. & $0.67(1.35)$ & $4.77(6.63)$ & $0.42(1.49)$ & -- \\
\hline 19 & Cuscuta pedicellata Ledeb. & -- & -- & -- & $2.39(2.77)$ \\
\hline 20 & Cynanchum acutum $\mathrm{L}$. & $16.41(18.74)$ & -- & 37.07 (42.65) & -- \\
\hline 21 & Cynodon dactylon (L.) Pers. & -- & -- & $27.71(35.78)$ & $34.82(9.64)$ \\
\hline 22 & Cyperus rotundus $\mathrm{L}$. & -- & $1.28(4.63)$ & $7.91(19.70)$ & -- \\
\hline 23 & Dactyloctenium aegyptium (L.) Willd. & -- & $12.86(16.61)$ & $22.95(41.41)$ & $1.27(2.53)$ \\
\hline 24 & Digitaria sanguinalis (L.) Scop. & -- & -- & $1.89(6.72)$ & $2.73(5.46)$ \\
\hline 25 & Dinebra retroflexa (Vahl) Panz. & -- & -- & $1.77(8.86)$ & -- \\
\hline 26 & Echinochloa colona $($ L.) Link & -- & -- & $6.24(16.05)$ & -- \\
\hline
\end{tabular}
the different vegetation communities in summer-autumn season resulted from TWINSPAN classification of the study area. 


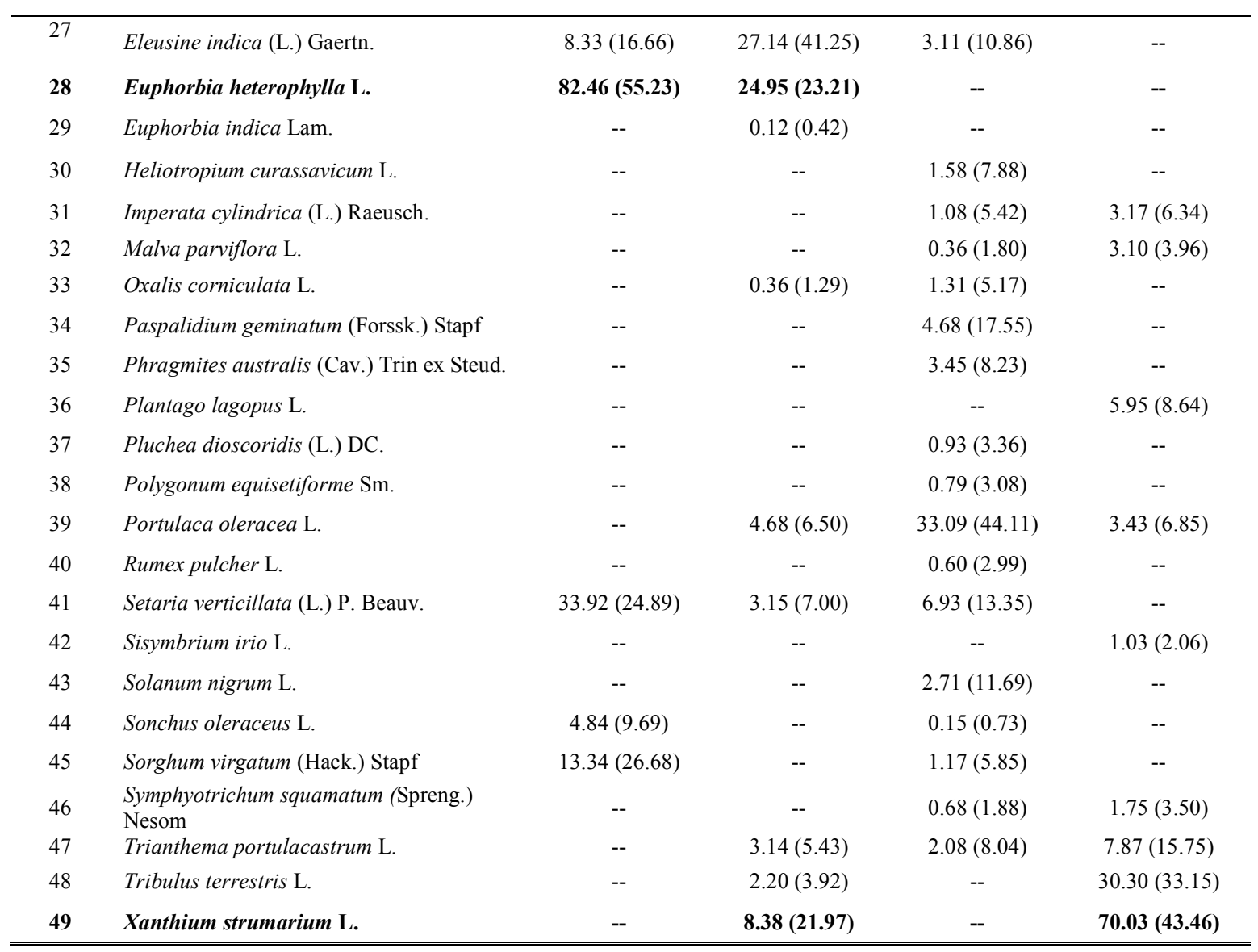

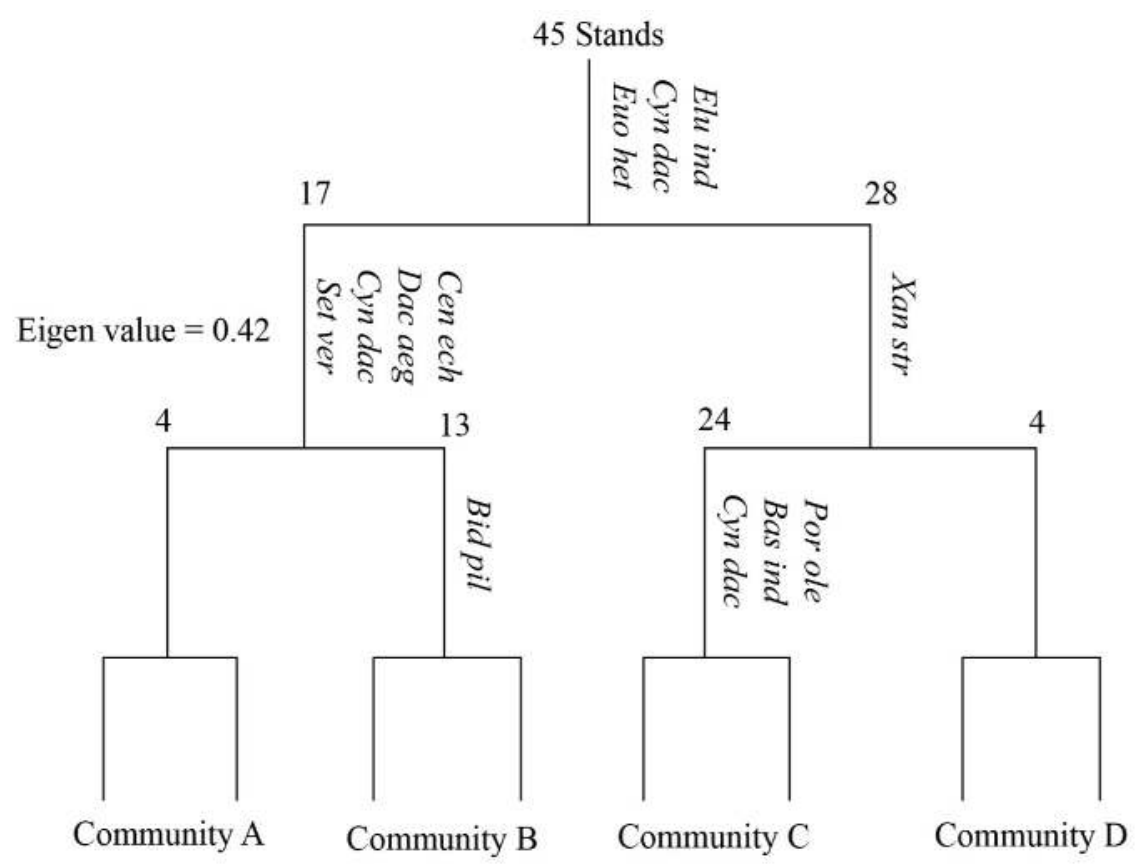

Figure (2): TWINSPAN dendrogram of 45 sampled summer-autumn stands based on the importance values of 49 Species. Elu. ind.. Eleusine indica; Cyn. Dac., Cynodon dactylon; Euo. Het, Euphorbia heterophylla; Xan. Str, Xanthium strumarium; Cen. Ech.,

Cenchrus echinatus, Dac. aeg., Dactyloctenium aegyptium; Set. ver., Setaria verticillata; Por. ole., Portulaca oleracea; Bas. ind., Bassia indica; Bid. pil., Bidens pilosa; EV, Eigen value.

\section{b) Ordination of stands}

The ordination of stands in the study area, given by Detrended Correspondence Analysis (DCA) is shown in Figure (3). The DCA ordinations of stands were indicated on the plane of the first and second DCA axes. It was clear that the plant communities obtained by TWINSPAN classification were markedly distinguishable and having a clear pattern of segregation on the ordination plane.

Community A (Euphorbia heterophylla) was sepa- 
rated at the right side of the DCA diagram. Community $\mathrm{B}$ (Commelina benghalensis) was also located at the right side of DCA diagram but up to group A. While, community $\mathrm{C}$ (Cynanchum actum) was obviously separated at the left side of the DCA diagram. The last community D (Xanthium strumarium) was also located at the left side but up of group $\mathrm{C}$ in DCA diagram. It was also noticed that the four plant communities (A-D) were clearly separated from each other, communities A and $\mathrm{B}$ seemed to be closely related to each other as well as communities $\mathrm{C}$ and $\mathrm{D}$, which may be attributed to the similarities in the floristic structure of each pair of the identified communities as shown in Figure (3).

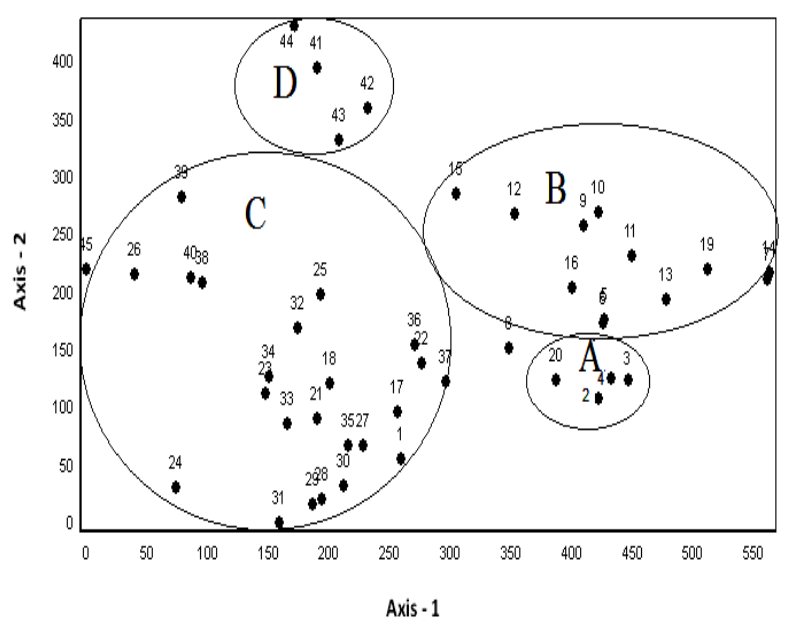

Figure (3):Detrended Correspondence Analysis (DCA) ordination diagram of 45 sampled summer-autumn season stands of the study area.

\section{Vegetation-Soil Relationships Soil variables-vegetation groups relationships}

The variation in soil variables (mean value \pm standard error) within the vegetation groups obtained by the TWINSPAN classification of the study area is shown in Table (2). All the identified plant communities (A, B, C \& D) showed a high significant variation with silt particles, where community (D) attained the highest value $(20.84 \%)$, while community (B) attained the lowest value $(3.99 \%)$. Also clay fraction showed a high significant variation, where community (D) attained the highest value (4.69\%), while community (B) attained the lowest value $(0.97 \%)$, but sand was obviously less significant than silt and clay. Calcium carbonate content attained the highest value $(15.06 \%)$ in community (D) and the lowest value $(2.90 \%)$ in community (B). Vegetation communities (A, B, C \& D) attained a moderately significant variation with $\mathrm{pH}$ value and total dissolved phosphorus content. These communities showed low significant variations with calcium, potassium, porosity, electrical conductivity, organic carbon, maximum water-holding capacity and the total nitrogen content. On the other hand, the communities (A, B, C \& D) exhibited non-significant variations in the remaining soil variables as shown in Table (2).

Concerning moderate significant variations, where it was noticed that the $\mathrm{pH}$ values recorded the highest value $(8.16 \%)$ in soils of community (D), while the lowest value $(7.35 \%)$ in community (A). Total dissolved phosphorus also attained the highest value (1.81 $\mathrm{mg} / 100 \mathrm{~g}$ dry soil) in community (D), while the lowest value $(0.44 \mathrm{mg} / 100 \mathrm{~g}$ dry soil $)$ in community (B).

Table (2): Mean value of the different soil variables $( \pm \mathrm{SE})$ at depth $(0-50 \mathrm{~cm})$ of the sampled stands representing the different plant communities obtained by TWINSPAN classification of the summer-autumn season. Por: porosity, TDP: total dissolved phosphorus, WHC: water-holding capacity, TN: total nitrogen, OC: organic carbon, SAR: sodium adsorption ratio, EC: electrical conductivity, LSD: Least Sigfnificant Difference.

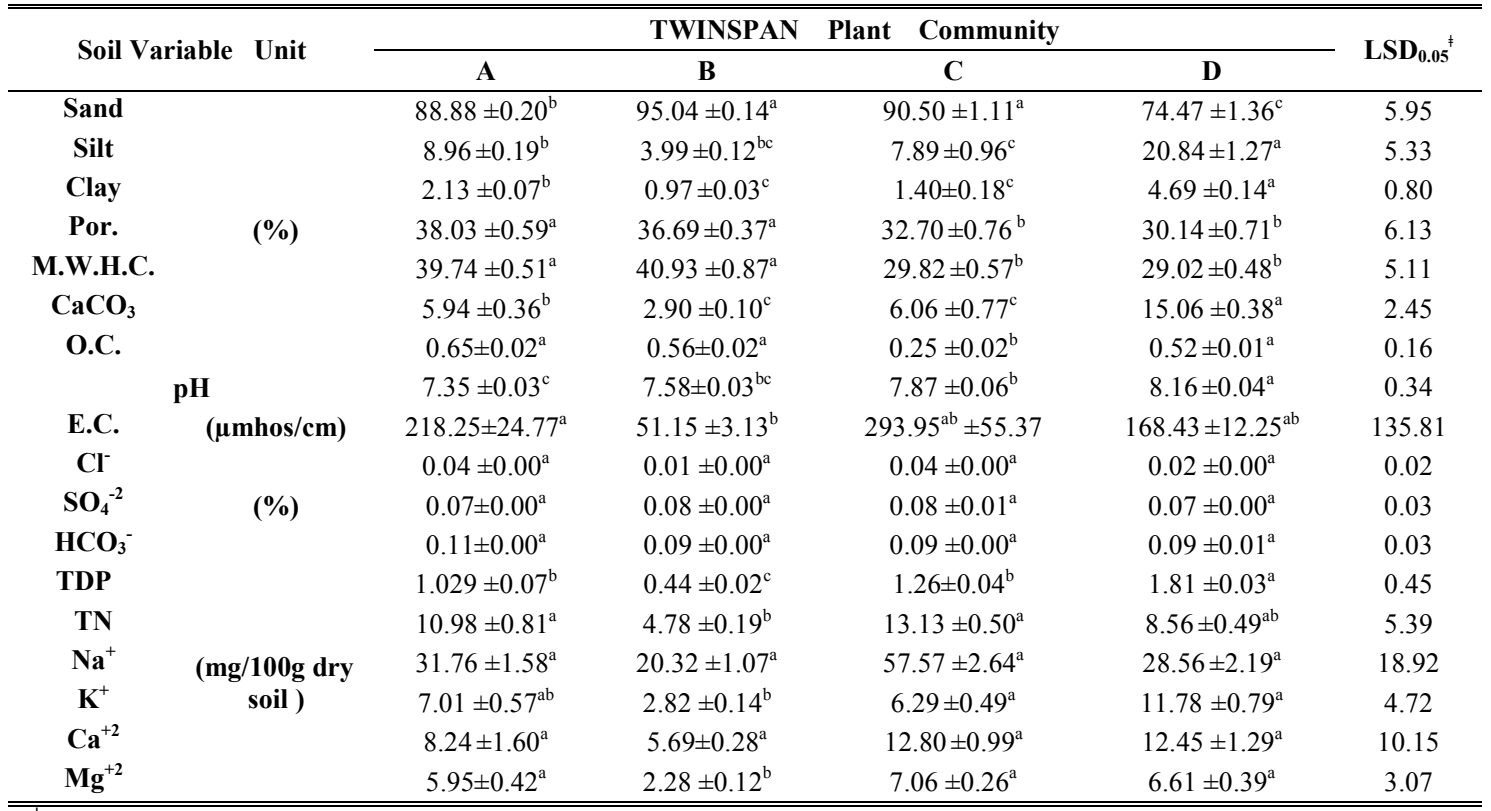

${ }^{\ddagger}$ Values with different superscript letters are significant different $(\mathrm{P} \leq 0.05)$.

On the other hand, concerning the low significant variations, it was also found that maximum water- holding capacity showed the highest value $(40.93 \%)$ in soils of community (B), while the lowest value 
$(29.02 \%)$ in community (D). Total nitrogen content exhibited the highest value $(13.13 \mathrm{mg} / 100 \mathrm{~g}$ dry soil $)$ in community (C), while the lowest value $(4.78 \mathrm{mg} / 100 \mathrm{~g}$ dry soil) in community (B). Calcium cation attained the highest value $(12.80 \mathrm{mg} / 100 \mathrm{~g}$ dry soil) in soils of community (C) and the lowest value $(5.69 \mathrm{mg} / 100 \mathrm{~g}$ dry soil) in community (B). Potassium cation attained the highest value $(11.78 \mathrm{mg} / 100 \mathrm{~g}$ dry soil) in soils of community (D) and the lowest value $(2.82 \mathrm{mg} / 100 \mathrm{~g}$ dry soil) in community (B). Electrical conductivity showed the highest value $(293.95 \mu \mathrm{mhos} / \mathrm{cm})$ in community (C) and the lowest value $(51.15 \mu \mathrm{mhos} / \mathrm{cm})$ in community (B). Organic carbon content showed the highest value $(0.65 \%)$ in soils of community (A) and the lowest value $(0.25 \%)$ in community $(\mathrm{C})$. Finally, soil porosity attained the highest value $(38.03 \%)$ in community (A) and the lowest value (30.14\%) in community (D).

\section{Plant-soil Pearson moment correlation (r)}

The results of plant-soil variables Pearson moment correlation are presented in Table (3). Sand fraction showed negative significant correlations with Cynodon dactylon and Xanthium strumarium $(P \leq 0.01)$. While, it attained a positively significant correlation with Dactyloctenium aegyptium and a negative correlation with Tribulus terrestris at propability level 0.05. Silt fraction exhibited positive significance with Cynodon dactylon and Xanthium strumarium $(P \leq 0.01)$. While, at propability level 0.05 , it attained a positively significant correlation with Tribulus terrestris and a negatively significant correlation with Dactyloctenium aegyptium. Clay faction showed positive correlations with Chenopodium album, Cynodon dactylon, Tribulus terrestris and Xanthium strumarium $(P \leq 0.01)$. However, a negative correlation was attained with Dactyloctenium aegyptium at propability level 0.05 . Porosity showed a negatively correlation with Cynodon dactylon $(P \leq 0.01)$, as well as negative correlations with Chenopodium album and Dactyloctenium aegyptium at propability level 0.05 , also it attained a positive significant correlation with Euphorbia heterophylla. Maximum water-holding capacity also attained positive significant correlations with Cenchrus echinatus and Euphorbia heterophylla, as well as it showed a negative significant correlation with Cynodon dactylon $(P \leq 0.01)$ while, at probability level 0.05 , it attained negative significant correlations with Bassia indica and Cynanchum acutum Calcium carbonate exhibited a positive significant correlation with Cynodon dactylon $(\mathrm{P} \leq 0.01)$. While, at propability level 0.05 , it showed positive significant correlations with Tribulus terrestris and Xanthium strumarium, as well as it showed a negative significant correlations with Cynanchuma-cutum and Dactyloctenium aegyptium. Organic carbon attained positive a significant correlation with Euphorbia heterophylla and a negative significant correlation with Cynanchum acutum $(P \leq 0.01)$. However, it showed a positive significant correlation with Sorghum virgatum and negative correlations with Dactyloctenium aegyptium and Portulaca oleracea at probability level 0.05 .
Measured $\mathrm{pH}$ value showed a positive significant correlation with Xanthium strumarium and a negative significant correlation with Bidens pilosa $(P \leq 0.05)$. Electrical conductivity exhibited a positive significant correlation with Bassia indica $(P \leq 0.01)$. Chlorides and sulphates both exhibited also a positive significant correlation with Bassia indica $(P \leq 0.05)$.

Bicarbonates exhibited a negative significant correlation with Chenopodium album only $(P \leq 0.05)$. Total dissolved phosphorus exhibited a positive significant correlation with Cynodon dactylon, and also it showed a negative significant correlation with Euphorbia heterophylla $(P \leq 0.01)$. At probability level 0.05 , it showed negative significant correlations with Cenchrus echinatus and Commelina benghalensis. Total nitrogen attained a positive significant correlation with Cynanchum acutum, while it showed negative significant correlations with Cenchrus echinatus, Commelina benghalensis and Euphorbia heterophylla $(P \leq 0.05)$.

Sodium exhibited a positive significant correlation with Cynodon dactylon $(P \leq 0.01)$. However, it showed positive significant correlations with Bassia indica and Cynanchum acutum, as well as it showed a negative significant correlation with Bidens pilosa at propability level 0.05. Potassium attained positive significant correlations with Chenopodium album and Tribulus terrestris $(P \leq 0.05)$. Calcium exhibited a positive significant correlation with Cynanchum acutum, while it attained a negative significant correlation with Euphorbia heterophylla $(P \leq 0.05)$. Magnesium exhibited negative significant correlations with Cenchrus echinatus, Commelina benghalensis and Euphorbia heterophylla, as well as it attained a positive significant correlation with Cynodon dactylon $(P \leq 0.05)$.

\section{Canonical correspondence analysis}

The correlation between vegetation and soil characteristics is indicated on the ordination diagram produced by Canonical Correspondence Analysis (CCA) of the recorded species and environmental (soil) variables. It was noticed that as shown in Figure (4), total dissolved phosphorus, magnesium, total nitrogen, sodium, maximum water-holding capacity and organic carbon showed relative high significant correlations with the first and second axes. While, calcium carbonate, silt and clay particles, potassium and calcium cations, sand particles and porosity exhibited moderate significant correlations. On the other hand, electrical conductivity, $\mathrm{pH}$ value, chlorides, sulphates and bicarbonates showed relative low significant correlations with the first and second axes of the CCA diagram.

In the upper right side of CCA diagram, community B which has dominant plant species namely, Commelina benghalensis and numerous important species such as Eleusina indica, Euphorbia heterophylla, Cenchrus echinatus and Dactyioctenium aegyptium were obviously controlled by organic carbon as shown in Figure (4). 


\section{Mashaly et al.}

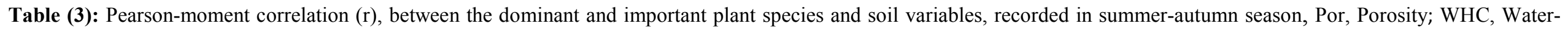
holding capacity; OC, Organic carbon; EC, Electrical conductivity; TDP, Total dissolved phosphorus; TN, Total nitrogen content.

\begin{tabular}{|c|c|c|c|c|c|c|c|c|c|c|c|c|c|c|c|c|c|c|}
\hline \multicolumn{19}{|c|}{ Soil variable } \\
\hline Plant species & Sand & Silt & Clay & Por. & $\begin{array}{l}\text { M.W.H } \\
\text {.C. }\end{array}$ & $\mathrm{CaCO}_{3}$ & O.C. & $\mathbf{p H}$ & $\begin{array}{c}\text { E.C. } \\
\mu \mathrm{mhos} / \\
\mathrm{cm}\end{array}$ & $\mathrm{Cl}^{-}$ & $\mathrm{SO}_{4}^{-2}$ & $\mathrm{HCO}_{3}^{-}$ & TDP & $\mathbf{T N}$ & $\mathrm{Na}^{+}$ & $\mathbf{K}^{+}$ & $\mathbf{C a}+{ }^{2}$ & $\mathrm{Mg}^{2}$ \\
\hline Bassia indica & -0.14 & 0.15 & 0.11 & -0.23 & $-.36^{*}$ & 0.22 & -0.24 & -0.15 & $.40^{* *}$ & $.31^{*}$ & $.32 *$ & -0.04 & 0.16 & 0.11 & $.34 *$ & -0.10 & 0.05 & 0.18 \\
\hline Bidens pilosa & 0.03 & -0.05 & 0.07 & -0.001 & 0.20 & -0.11 & 0.17 & $-.31^{*}$ & -0.09 & -0.04 & -0.13 & 0.25 & 0.01 & 0.08 & $-.34^{*}$ & 0.12 & 0.13 & 0.03 \\
\hline Cenchrus biflorus & -0.08 & 0.09 & 0.06 & 0.10 & 0.11 & 0.10 & 0.10 & -0.03 & -0.12 & -0.11 & 0.03 & 0.18 & -0.10 & -0.16 & -0.19 & -0.03 & -0.19 & -0.23 \\
\hline Cenchrus echinatus & 0.16 & -0.16 & -0.12 & 0.16 & $.41^{* *}$ & -0.15 & 0.21 & 0.07 & -0.09 & -0.06 & 0.01 & -0.02 & $-.35^{*}$ & $-.31^{*}$ & -0.28 & -0.21 & -0.18 & $-.34 *$ \\
\hline Chenopodium album & -0.18 & 0.14 & $.41^{* *}$ & $-.31^{*}$ & -0.18 & 0.23 & 0.16 & 0.04 & 0.04 & -0.01 & -0.15 & $-.33^{*}$ & 0.26 & 0.03 & -0.10 & $.31 *$ & -0.09 & -0.06 \\
\hline $\begin{array}{l}\text { Commelina } \\
\text { benghalensis }\end{array}$ & 0.18 & -0.17 & -0.17 & 0.19 & 0.24 & -0.158 & 0.20 & -0.15 & -0.14 & -0.16 & 0.01 & 0.02 & $-.35^{*}$ & $-.31^{*}$ & -0.26 & -0.20 & -0.17 & $-.33 *$ \\
\hline Cynonchum acutum & 0.11 & -0.07 & -0.22 & -0.09 & $-.30^{*}$ & $-.29^{*}$ & $-.55^{* *}$ & 0.20 & 0.01 & 0.07 & -0.11 & -0.12 & 0.21 & $.31 *$ & $.29^{*}$ & 0.21 & $.33^{*}$ & 0.27 \\
\hline Cynodon dactylon & $-.43 * *$ & $.42 * *$ & $.42^{* *}$ & $-.57 * *$ & $-.51^{* *}$ & $.38^{* *}$ & -0.27 & 0.22 & 0.22 & 0.15 & 0.13 & 0.02 & $.39^{* *}$ & 0.29 & $.39^{* *}$ & 0.09 & 0.08 & $.34 *$ \\
\hline $\begin{array}{l}\text { Dactyloctenium } \\
\text { aegyptium }\end{array}$ & $.34 *$ & $-.33 *$ & $-.34 *$ & $-.33^{*}$ & -0.22 & $-.30^{*}$ & $-.35^{*}$ & 0.13 & -0.16 & -0.20 & -0.04 & -0.15 & 0.08 & 0.22 & -0.04 & 0.16 & 0.28 & 0.16 \\
\hline Eleusine indica & 0.16 & -0.16 & -0.10 & 0.08 & 0.23 & -0.09 & 0.23 & -0.20 & -0.16 & -0.16 & -0.17 & 0.05 & -0.29 & -0.22 & -0.26 & -0.20 & -0.15 & -0.25 \\
\hline $\begin{array}{l}\text { Euphorbia } \\
\text { heterophylla }\end{array}$ & 0.10 & -0.09 & -0.07 & $.35^{*}$ & $.44^{* *}$ & -0.09 & $.51^{* *}$ & -0.26 & -0.09 & -0.04 & 0.01 & -0.05 & $-.41 * *$ & $-.34 *$ & -0.22 & -0.21 & $-.37 *$ & $-.35^{*}$ \\
\hline Portulaca oleracea & -0.12 & 0.12 & -0.02 & 0.09 & -0.15 & -0.18 & $-.30^{*}$ & -0.02 & 0.15 & 0.22 & -0.12 & -0.08 & 0.16 & 0.24 & 0.24 & 0.14 & 0.22 & 0.20 \\
\hline Setaria verticillata & 0.01 & -0.001 & -0.04 & 0.23 & 0.11 & 0.03 & 0.21 & -0.17 & 0.14 & 0.20 & 0.09 & 0.11 & -0.10 & 0.02 & -0.02 & -0.05 & -0.13 & -0.01 \\
\hline Sorghu virgatum & -0.01 & -0.05 & 0.09 & 0.20 & 0.20 & 0.05 & $.32 *$ & -0.08 & -0.08 & -0.08 & 0.02 & -0.01 & -0.13 & -0.11 & -0.04 & -0.07 & -0.22 & -0.11 \\
\hline Tribulus terrestris & $-.33^{*}$ & $.30^{*}$ & $.49^{* *}$ & -0.22 & -0.09 & $.32 *$ & 0.23 & 0.12 & 0.01 & -0.04 & -0.13 & -0.23 & 0.27 & -0.13 & -0.23 & $.36^{*}$ & 0.03 & 0.02 \\
\hline $\begin{array}{l}\text { Xanthium } \\
\text { strumarium }\end{array}$ & $-.47 * *$ & $.47^{* *}$ & $.46^{* *}$ & -0.01 & -0.01 & $.37 *$ & 0.12 & $.30^{*}$ & -0.10 & -0.12 & -0.03 & 0.16 & 0.23 & -0.24 & -0.26 & 0.27 & 0.10 & 0.05 \\
\hline
\end{tabular}

***, Variable are significant at $p \leq 0.001 ; * *$ : significant at $p \leq 0.01$, and *: significant at $p \leq 0.05$. 
In the lower right side of CCA diagram, community A which has dominant plant species namly, Euphorbia heterophylla and many important species such as Setaria verticillata, Bidens pilosa, Cynanchum acutum and Sorghum virgatum were obviously controlled by maximum water-holding capacity, porosity and sand fraction (Figure 4).

In the upper middle side of CCA diagram, community D which has dominant plant species Xanthium strumarium and some important species such as Cynodon dactylon, Tribulus terrestris, Cenchrus biflorus and Chenopodium album were obviously controlled by calcium carbonate, clay fraction (Figure 4). In the lower left side of CCA diagram, community $\mathrm{C}$ which has dominant plant species Cynanchum acutum and the important species namely, Portulaca oleracea, Cynodon dactylon, Dactyioctenium aegyptium and Bassia indica were obviously controlled by many soil variables such as organic carbon, calcium carbonate, silt particle, sodium, potassium, calcium, magnesium, total dissolved phosphorus, total nitrogen, electrical conductivity and $\mathrm{pH}$ value (Figure 4).

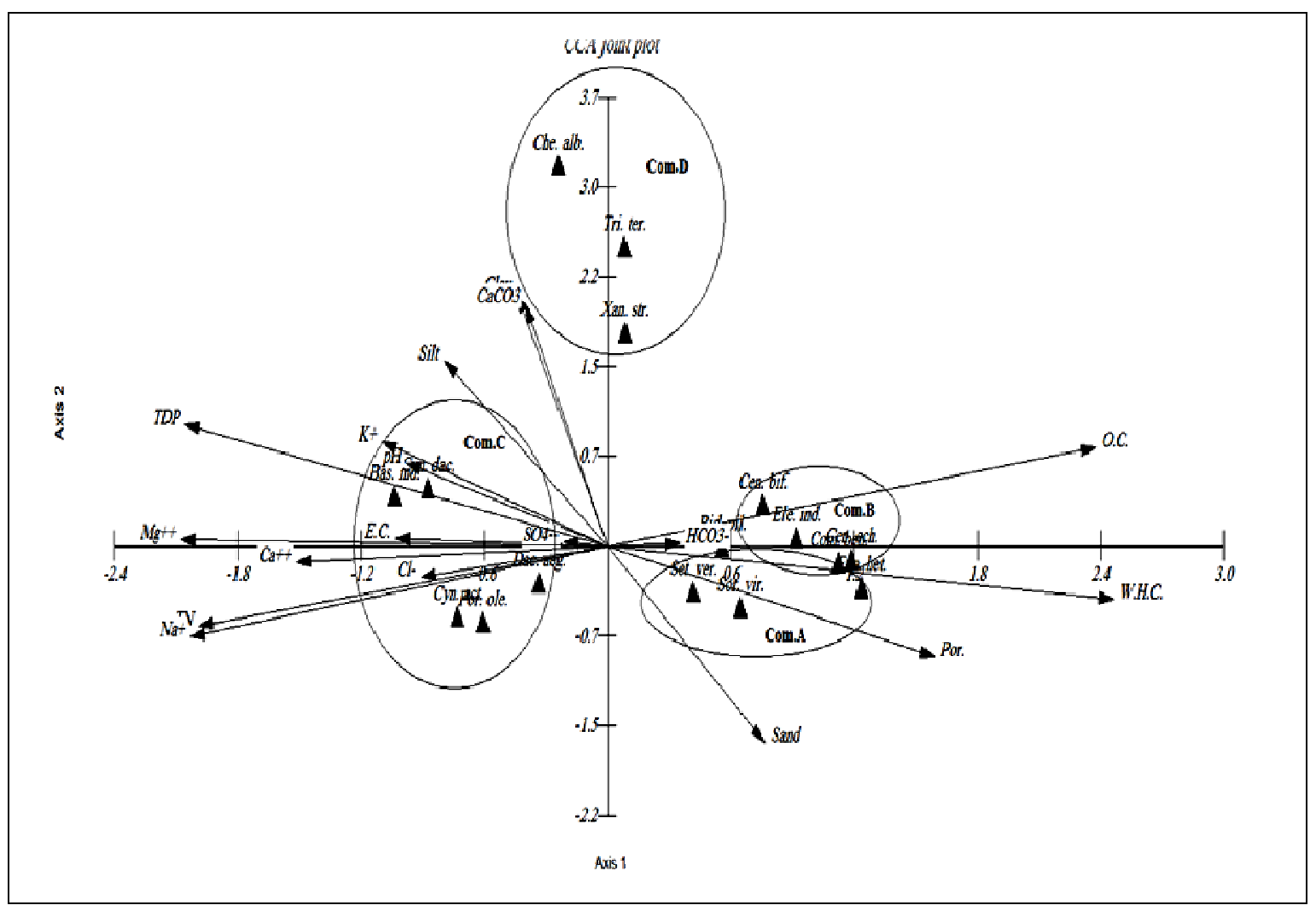

Figure (4): Canonical Correspondence Analysis (CCA) ordination diagram of plant species during summer-autumn season along the gradient soil variables (arrows).

\section{Diversity measurements of vegetation groups Shannon-Wiener (H') and Shannon-Evenness (E) diversity indices}

It was obvious that community $A$ attained the highest value 2.67 of the Shannon-Wiener $\left(\mathrm{H}^{\prime}\right)$, followed by community $\mathrm{C}$ which attained the value of 2.50. While, communities B and D showed the lowest values 2.44 and 2.32, respectively as shown in Figure (5).

The vegetation groups obtained from TWINSPAN classification demonstrated differences in ShannonEvenness diversity index (E) as shown in Figure (6). Community A attained also the highest values of Shannon-evenness diversity index $(0.88)$, followed by community $\mathrm{B}$ which attained the value of 0.81 , while communities $\mathrm{D}$ and $\mathrm{C}$ attained the lowest values 0.79 and 0.69 , respectively.

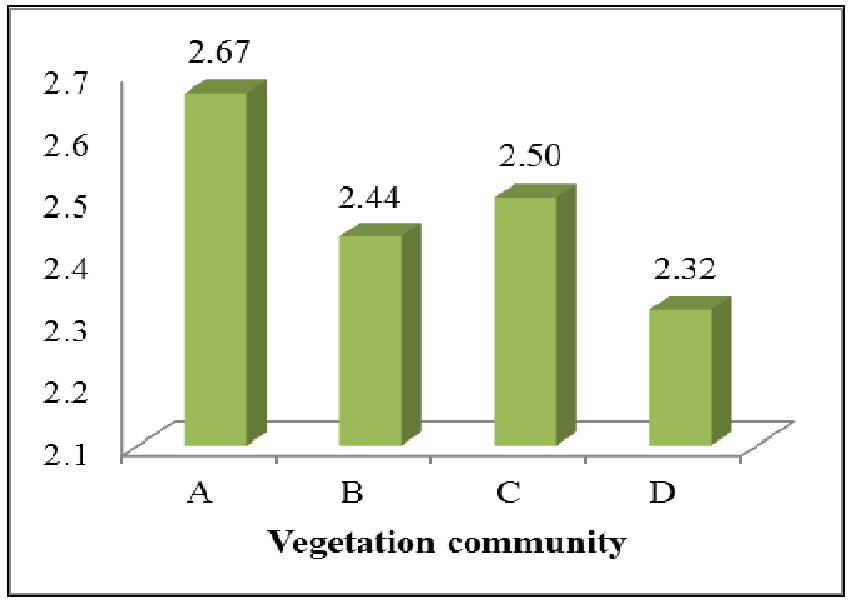

Figure (5): Shannon-Wiener diversity index $\left[\mathrm{H}^{\prime}\right]$ of the four summer-autumn plant communities derived from the TWINSPAN classification. 


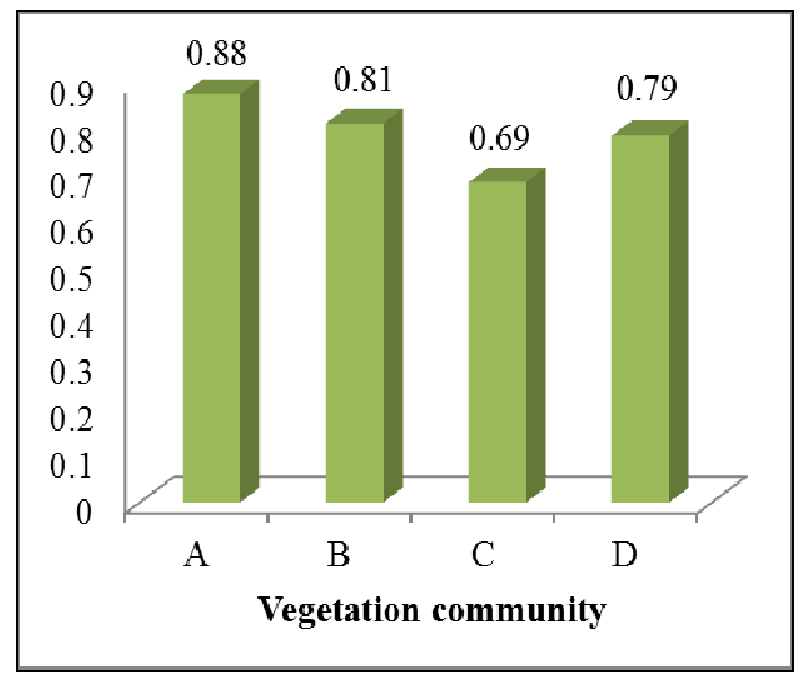

Figure (6): Shannon-Evenness diversity index [E] of the four summer-autumn plant communities derived from the TWINSPAN classification.

\section{Simpson's diversity index}

The plant communities also demonstrated differences in the Simpson's diversity index (D) as shown in Figure (7). It was clear that community A attained the highest value 0.92 of Simpson's diversity index. While the other communities B, C and D attained a close values $(0.87,0.865$ and 0.864 , respectively).

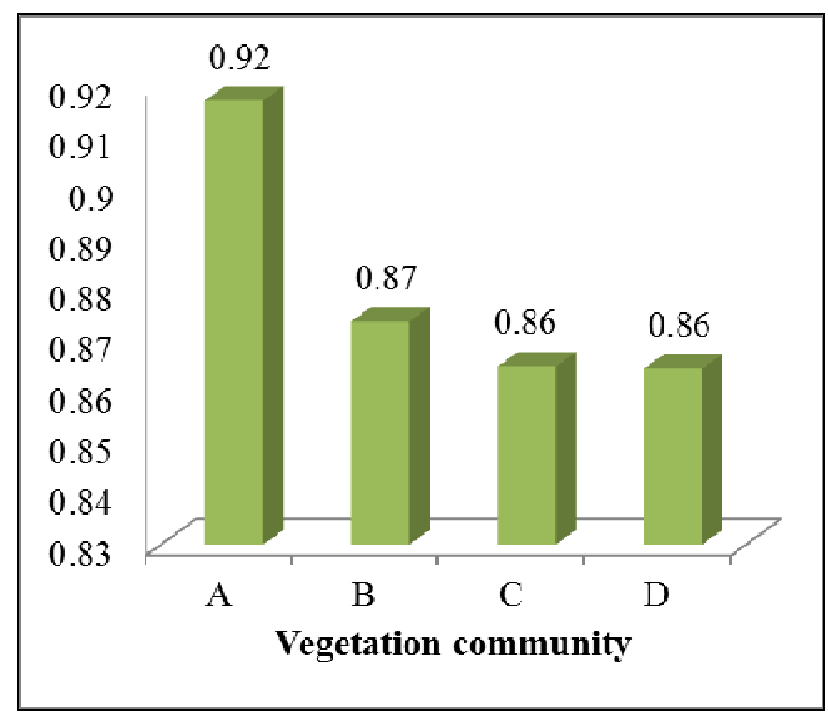

Figure (7): Simpson's Diversity index (D) of the four summer-autumn plant communities obtained from the TWINSPAN classification.

\section{DISCUSSION}

Modern synecological studies are used more objective methodology at a local and sometimes regional scale, which search to reduce the complexity of a set of field data by either classification and/or ordination based on floristic data. Then vegetation analysis has been related to environmental data. Instead of that, vegetation-habitat relationships have been derived from a single analysis of combined floristic and environmental variables (ter Braak, 1987).
The implementation of TWINSPAN classification based on the importance values of 49 plant species recorded in 45 sampled stands representing various orchard types carried out through summer-autumn season from the study areas. The vegetation in the study areas is classified into four vegetation groups derived by TWINSPAN classification. Groups comprise a number of sampled stands, which are comparable in terms of vegetation and characterized by dominant and/or codominant species, as well as by a number of the indicator and/or preferential species.

In summer-autumn season, group A was dominated by the toxic plant Euphorbia heterophylla. It has various medicinal properties, in addition, to its antioxidant, cytotoxic, and antimicrobial activities (Adedoyin et al., 2013) which may cause its dominance. It is an annoying weed in gardens and along roadsides, it can exist from sea-level up to $3,000 \mathrm{~m}$ high. Furthermore, around 45-50 days is a life cycle of a plant and is thus capable of many life cycles per rainy season. This plant can be flowering and fruiting throughout the year, so it causes great concern for its high capacity and competitive ability with crops (Chemale and Fleck, 1982). Group B was dominated by Commelina benghalensis. It has numerous therapeutics activities like burns, boils, laxative, leprosy, nervous disorders and swellings (Parekh and Chanda, 2007). It has also antimicrobial activity (Ahmed et al., 2001) and antitumor activity (Rahman, 1994). Moreover, it used for coughs and colds, spathe liquid against female infertility, female cleaning and fodder (Maundu et al., 2001). All the previous activities of this plant were corroborated to the various bioactive compounds, which make the plant more competitive, which may play a role in its dominance. Additionally, Commelina benghalensis is an aggressive weed, which produces viable seed from both above and below by ground aerial and subterranean buds as it has the ability to propagate by nodes of root and from cut stems. Thus, light cultivation can easily break plant parts and increase the area of invasion. Group $\mathrm{C}$ was dominated by Cynanchum acutum, which is an important medicinal plant used by people in rural areas. In addition, it possesses anti-microbial effects (Dehghani et al., 2012). This species takes place in different habitats such as moist soils, close to freshwater, brackish water rivers, wastelands, reed beds and gardens. It is a liana that could cause a negative impact on the local vegetation and orchards. It was found in many reclaimed areas such as peach, apple, maize and wheat cultivations. Because of its strong growth, it provides a dense canopy above its holding plant, which reduces photosynthesis (Akhani, 2014). Group D was dominated by Xanthium strumarium characterized by it's an allelopathic effect (Konstantinovic et al., 2013). Gaikwad et al. (2016) reported that it possess useful medicinal properties such as antibacterial, antitumour and anticancer. The success of Xanthium strumarium as an invasive species because of its competitive genetic makeup (Gray et al., 1986) among other adaptive capabilities that the species possesses (Chikuruwo et al., 2017).

The ordination has been defined by Goodall (1954) 
as "an arrangement of units in a uni- or multidimensional order". The emphasis is on the arrangement of sample units (species or stands) by individual values rather than by group, values would result in classification. Ordination of species and stands is a necessary step prior to any good floristic classification (Mueller-Dombois and Ellenberg, 1974). Detrended Correspondence Analysis (DCA) as derived by Hill (1979a) is an attempt to improve upon reciprocal averaging (RA).

The DCA ordination in the sampled stands in summer-autumn season indicated that the vegetation groups obtained by TWINSPAN classification having a clear pattern of the distinction between different vegetation groups on the ordination planes. All the vegetation groups were located on the positive side of the first and second ordination axes. It is obvious that communities A and B were clearly separated in right part of the ordination plot, and this is due to the similarity in the vegetative structure between these two groups. While communities $\mathrm{C}$ and $\mathrm{D}$ were clearly separated in the left part of the ordination plot, this is may be also due to the vegetation similarity between them.

Canonical Correspondence Analysis (CCA) is a type of multivariate direct gradient analysis method, which has become very widely used in different ecological studies. This method is derived from correspondence analysis, where the environmental data is incorporated into the analysis. Reciprocal averaging from the correspondence analysis is calculated using it. Although, a multiple regression is performed on the sample scores on the environmental variables at each cycle of the averaging process. New site scores are calculated based on this regression, and then the process is repeated until the scores stabilize. The result is the axes of the final ordination, rather than easily reflecting the dimension of the greatest variability in the species data, are restricted to be a linear combination of the environmental variables and the species data. So these two sets of data are finally related to each other directly (Kovach Computing Services, 1985-2002).

In the present phytosociological study, the application of Canonical Correspondence Analysis between the position of vegetation groups on the ordination planes and soil variables of their stands illustrate that the most important soil factors controlling the distribution of weed vegetation in summer-autumn season were total dissolved phosphorus, magnesium, total nitrogen, sodium, maximum water-holding capacity and organic carbon. These results agreed more or less with those investigated by Shehata and El-Fahar (2000), Mashaly (2001 \& 2003, Mashaly and Awad (2003), Galal and Fawzy (2007), Mashaly et al. (2008), Maswada (2009), Mashaly et al. (2009), Abd El-Gawad (2010), Deweeb (2015) and AL-Nafie (2015).

The correlation coefficient between the soil factors in summer-autumn showed that some soil variables were correlated with others with different degrees. This agreed more or less with that investigated by Omar (2006) on the plant life of different habitats in the north
Nile Delta of Egypt, Abd El-Gawad (2008) studies on the ecology of some non-conventional forage weeds in Nile Delta, Egypt, Deweeb (2015) on ecology and economic potentialities of some species of genus Plantago in Egypt and AL-Nafie (2015) on environmental impact of land reclamation on plant diversity in the Nile Delta coast of Egypt.

The species richness and evenness variations among the different habitat types may be assigned to the difference in soil properties, substrate discontinuities and the allelopathic effect of one or more plant species due to their relative dominance among other associated species (Hegazy et al., 1994; EL-Khatib et al., 2004; James et al., 2006). This agree with the findings of Mellinger and McNaughton (1975) who provide evidence that a high level of species diversity would be caused by a local differentiation in soil properties around individual plants Whittaker and Levin (1977) suggested that heterogeneity of environments allows satisfaction of the requirements of many species within a community. Meanwhile, species diversity increased as the number of species per sample increased, and the abundance of species within a sample became even (Pielou, 1969). Consequently, the vegetation group A in summer-autumn season is more diverse than those of the other groups. This could be attributed to the vegetation structure and habitats composition.

\section{REFERENCES}

ABD EL-GAWAD, A.M. 2008. Ecological Studies on some Non-Conventional Forage Weeds in Nile Delta, Egypt. M.Sc. Thesis, Faculty of Science, Mansoura University, Egypt.

ABD EL-GAWAD, A.M. 2010. Weeds and Invasive Plants in Some Newly Reclaimed Areas in Egypt: Ecology, Allelopathy and Economic Potentialities. Ph.D. Thesis, Faculty of Science, Mansoura University, Egypt.

ADEDOYIN, B. J., S. O OKENIYI, S.GARBA AND L.SALIHU 2013. Cytotoxicity, antioxidant and antimicrobial activities of essential oil extracted from Euphorbia heterophylla plant. Topclass Journal of Herbal Medicine, 2: 84-89.

AHMED, F., G.M. RAHMAN AND A.K. DAS 2001. Antimicrobial activity of Commolina benghalensis. K.U. Studies, 3: 531-532.

AKHANI, H. 2014. Cynanchum acutum. The IUCN Red List of Threatened Species 2014: e.T19181578A21248535.http://dx.doi.org/10.2305/ IUCN.UK.2014-1.RLTS.T19181578A21248535.en

ALLEN, S.E., H.M.GRIMSHAW, J.A. PARKINSON, C. QUARMBY AND J.D. ROBERTS 1974. Chemical Analysis of Ecological Materials. Osney Blackwell Scientific Publ., Oxford, London.

AL-NAFIE, R. 2015. Environmental Impact of Land Reclamation on Plant Diversity in the Nile Delta Coast of Egypt. M.Sc. Thesis, Faculty of Science, Mansoura University, Egypt.

ANONYMOUS 1993. SPSS Program for Windows. Base System User's Guide Release 5.0.2 Marija J. Norsis/SPSS INC.

APHA 1998. Standard Methods for the Examination of Water and Waste Water. American Public Health 
Association, American Water Work Association, Water Pollution Control Federation, Washington, D.C.

BAESSLER, C.AND S. KLOTZ 2006. Effects of changes in agricultural land-use on landscape structure and arable weed vegetation over the last 50 years. Agriculture, ecosystems \& environment, 115(1): 43-50.

BOULOS, L. 1999-2005. Flora of Egypt. Vols. 1-4. Al Hadara Publishing, Cairo, Egypt.

BOULOS, L. 2009. Flora of Egypt Checklist, Revised Annotated Edition. Al Hadara Publishing, Cairo, Egypt.

CHEMALE, V.M. AND N.G. FLECK 1982. Avaliação de cultivares de soja (Glycine max (L.) Merrill) em competição com Euphorbia heterophylla L. sob três densidades e dois períodos de ocorrência. Planta Daninha, v.5, n. 2 (April-June), p. 36-45. ISSN: 0100- 8358

CHIKURUWO, C., M. M. MASOCHA AND H. ANDAIMANI, 2017. Predicting the suitable habitat of the invasive Xanthium strumarium L. in Southeastern Zimbabwe. Applied Ecology and Environmental Research, 15 (1): 17-32.

DEHGHANI, M., Z. GANJALI, F. JAVADIAN, J. ESTAKHRAND A. HEIDARI 2012. Antimicrobial activity of ethanolic and aqueous extract of Cynanchum acutum. British Journal of Pharmacology and Toxicology, 3(4): 177-180.

DEWEEB, M.R. 2015. Ecology and Economic Potentialities of some Species of Genus Plantago in Egypt. M.Sc. Thesis, Faculty of Science, Mansoura University, Egypt.

DWYER, J., AND T.J. ENTWISLE 2016. Weeds, Plants, and People. Pen Folk Publishing. Australia.

EL-KHATIB, A.A., A.K. HEGAZY AND H.K. GALAL 2004. Allelopathy in the rhizosphere and amended soil of Chenopodium murale L. Weed Biology and Management, 4 (1): 35-42.

ELLENBERG, H. AND D. MUELLER-DOMBOIS 1974. Aims and Methods of Vegetation Ecology. John Wiley and Sons, New York, Chichester, Brisbane, Toronto.

FAO. 2005. Fertilizer Use by Crop in Egypt, Food and Agriculture Organization of the United Nations, Land and Plant Nutrition Management Service, Land and Water Development Division, Rome.

GAIKWAD, S., R. TORANE, AND K. MUNDHE 2016. Preliminary Screening and Comparative Evaluation of Antioxidant Potential of Medicinally Important Plant Xanthium Strumarium L. Journal Of Pharmacognosy And Phytochemistry, 5(2): 141.

GALAL, T.M. AND M. FAWZY2007. Sand dune vegetation in the coast of Nile Delta, Egypt Global Journal of Environmental Research, 2: 74-85.

GAUCH, H.G. AND R.H. WHITTAKER 1981. Hierarchical classification of community data. Journal of Ecology, 69: 537-557.

GOODALL, D.W. 1954. Objective Methods for The Classification of Vegetation. III. An Essay in the Use of Factor Analysis. Australian Journal of Botany, 2 (3): 304-324.

GRAY, A. J., R. N.MACK, J. L.HARPER, M. B.
USHER, K. JOYSEY AND H. Kornberg 1986. Do Invading Species Have Definable Genetic Characteristics? [and Discussion]. Philosophical Transactions of the Royal Society of London B: Biological Sciences, 314(1167): 655-674.

HEGAZY, A.K., M.I. SOLIMAN AND I.A. MASHALY 1994. Perspectives on the biology of Heliotropium curassavicum in the Deltaic Mediterranean coast of Egypt. Arab Gulf Journal of Scientific Research, 12: 525-545.

HENDERSON, P.A. AND R.M.H. SEABY 1999. Community Analysis Package (CAP) version 1.2. Pisces Conservation Ltd. IRC House, UK.

Hill, M.O. 1979a. DECORANA-A FORTRAN Program for Detrended Correspondence Analysis and Reciprocal Averaging. Section of Ecology and Systematic, Cornell University, Ithaca, New York.

Hill, M.O. 1979b. TWINSPAN-a FORTRAN Program for Arranging Multivariate Data in an Ordered Two Way Table by Classification of Individual and Attributes. Section of Ecology and Systematic Cornell University, Ithaca, New York.

HILL, M.O. AND P. ŠMILAUER 2005. TWINSPAN for Windows version 2.3. Centre for Ecology and Hydrology; University of South Bohemia, Huntingdon and České Budějovice.

JACKSON, M.L. 1967. Soil Chemical Analysis. Constable and Co. LTD. London.

JAMES, J.J., M.A. CAIRD, R.E. DRENOVSKY AND R.L. SHELEY 2006. Influence of Resource Pulses and Perennial Neighbors on the Establishment Of An Invasive Annual Grass In The Mojave Desert. Journal of Arid Environments, 67 (3): 528-534.

KONSTANTINOVIC, B., M. BLAGOJEVIC AND N. SAMARDZIC 2013. Allelopahtic Effect of Xanthium Strumarium L. and Abuthilon Theophrasti Med. Extracts on Germination of Maize and Soybean Seed. In Fourth International Scientific Symposium" Agrosym 2013", Jahorina, Bosnia and Herzegovina, 3-6 October, 2013. Book of Proceedings (: 630-635). Faculty of Agriculture, University of East Sarajevo.

KOVACH COMPUTING SERVICES 1985-2002. Multivariate Statistical Package (MVSP, Version 3.13c). http:/www.kovach.com.

KREBS, C.J. 1985. Species Diversity, Ecology The Experimental Analysis of Distribution and Abundance. Harper Collins, New York.

MAGURRAN, A.E. 1988. Ecological Diversity and its Measurement. Springer Netherland, Princeton, New Jersey.

MASHALY, I.A. 2001. Contribution to the ecology of the Deltaic Mediterranean coast, Egypt. Online Journal of Biological Science, 1(7): 628-635.

MASHALY, I.A. 2003. Phytosociological study on the weed flora of crop lands in Kafr El-Sheikh Governorate, Egypt. El-Minia Science Bulletin, 14 (2): 127-153.

MASHALY, I.A. AND E.R. AWAD, 2003. Ecological perspectives on the weed flora of orchards in the Nile Delta, Egypt. Journal of Environmental Sciences, Mansoura University, 25: 1-37.

MASHALY, I.A., E.E. EL-HABASHY, E.F. EL- 
HALAWANY AND G. OMAR 2008. Habitats and plant communities in the Nile Delta of Egypt. IDeltaic Mediterranean coastal habitat. Pakistan Journal of Biological Sciences, 11 (22): 2532-2544.

MASHALY, I.A., E.E. EL-HABASHY, E.F. ELHALAWANY AND G. OMAR 2009. Habitats and plant communities in the Nile Delta of Egypt. IIIrrigation and drainage canal bank habitat. Pakistan Journal of Biological Sciences, 12 (12): 885-895.

MASWADA, H.F. 2009. Ecological and Physiological Studies on some Geophytes in the Mediterranean Coastal Region of Kafr El-Sheikh Governorate, Egypt. Ph.D. Thesis, Faculty of Agriculture, Tanta University, Tanta, Egypt.

MAUNDU, P., D. BERGER, C. OLE SAITABAU, J. NASIEKU, M. KIPELIAN, S. MATHENGE, Y. MORIMOTO AND R. HÖFT, 2001. Ethnobotany of the Loita Maasai People and Plants. Working Paper 8. UNESCO, Paris.

MELLINGER, M.V. AND S.J. MCNAUGHTON, 1975. Structure and function of successional vascular plant communities in central New York. Ecological Monographs, 45: 161-182.

Mueller-Dombois, D. And H. Ellenberg 1974. Aims and Methods of Vegetation Ecology. John Wiley and Sons, New York, Chichester, Brisbane, Toronto.

OMAR, G. 2006. Plant Life of the Different Habitats in the North Nile Delta of Egypt: Ecology and Fodder Potentialities. Ph.D. Thesis, Faculty of Science, Mansoura University, Egypt, Mansoura, Egypt.

PAREKH, J. AND S. CHANDA 2007. In vitro antimicrobial activity and phytochemical analysis of some Indian medicinal plants. Turkish Journal of Biology, 31: 53-58.

PIELOU, E.C. 1969. An Introduction to Mathematical Ecology. Willey Interscience, New York, USA.

PIERCE, W.C., E.L. HAENISCH AND D.T. SAWYER 1958. Quantitative Analysis. Wiley Toppen, Tokyo.

PIPER, C.S. 1947. Soil and Plant Analysis. Interscience Publishers, Inc, New York, USA. ami

PIRIE, N.W. 1955. Protein. In: Peach, K., Tracey,
V.M. (Ed.), Modern Methods of Plant Analysis. Springer Verlage, Berlin.

PYSEK, P., V. JAROSIK, AND T. KUCERA 2002. Patterns of invasion in temperate nature reserves. Biological Conservation, 104: 13-24.

RAHMAN, G.M. 1994. Anti-Tumor Activity of Commolina benghalensis. M.Sc. Thesis Department of Pharmacy, University of Dhaka, Bangladesh. p. 23.

SARANT, L. 2017. Egypt: Space to grow. Nature, 544(7651): S14-S16.

SHEHATA, M.N. AND R.A. EL-FAHAR 2000. The vegetation of reclaimed areas in Salhya region. The 1st International Conference on Biological Science, Tanta, Egypt.

SHUKLA, R.S. AND P.S. CHANDEL 1989. Plant Ecology and Soil Science. S. Chand \& Company LTD. Ram Nagar, New Delhi, India.

SNEDECOR, G.W. AND W.G. COCHRAN 1968. Statistical Methods. The Iowa State University Press, USA.

TACKHOLM, V. 1974. Students' Flora of Egypt. Cairo University Press. Cairo, Egypt.

TER BRAAK, C.J.F. 1987. The analysis of vegetationenvironment relationships by canonical correspondence analysis. Vegetatio, 69: 69-77.

VIRTUE, J. G. AND R. L. MELLAND 2003. The Environmental Weed Risk of Revegetation and Forestry Plants. Report DWLBC 2003(02). Department of Water, Land and Biodiversity Conservation South Australia, Adelaide. p. 184.

WALKER, B. AND W. STEFFEN, 1997. An overview of the implications of global change for natural and managed terrestrial ecosystems. Conservation Ecology,1(2):2. http://www.consecol.org/Journal/vol1/iss2/art2/.

WHITTAKER, R.H. AND S.A. LEVIN, 1977. The role of mosaic phenomena in natural communities. Theoretical Population Biology, 12 (2): 117-139.

WITTIG, R. 2002. Siedlungs Vegetation. Stuttgart: Eugen Ulmer (in German).

ZIMDAHL, R.L. 2007. Fundamentals of Weed Science. 3rd ed. Academic Press. California-USA. 
بيئة الاعثاب في حدائق الفاكهة اثناء فصل الصيف في منطقة دلتا النيل- مصر

$$
\text { قسم النباتـ كثلية العلوم- جامي البرطية ـ أحمد عبدالجواد المنصورة- مصر. }
$$

\section{الملخص العربــي}

يهدف هذه البحث إلى در اسة بيئة مجتمعات الحشائش المرتبطة ببعض حدائق الفاكهة في فصل الصيف باستخدام الاختلافات في العو امل البيئية لتحديد توزيع وفرة مجتمعات الحشائش في مناطق الدراسة. تم نوزيع المو اقع في أربع محافظات. بدأت الزيارات

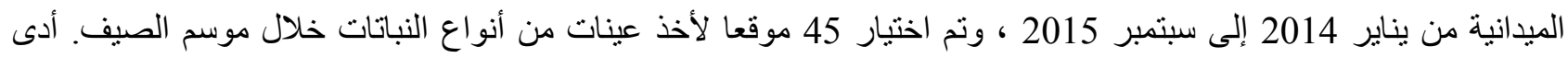

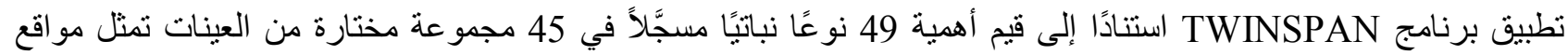
البساتين الصيفية في مناطق الدر اسة ، تم تحديدها بأربع مجمو عات (نبات لبن الحمارة، نبات هاد إيب، نبات العليق، نبات الثبيط كانت النباتات السائدة). في موسم الصيف ، أثبت تطبيق تقنية DCA أن مجتمعات النباتات التي تم التعرف عليها من خلال تصنيف كانت مميزة بشكل ملحوظ ولديها نمط واضح من الفصل على مستوى التنسيق. تم استخدام تطبيق CCAINSPAN متغير ات التربة الأكثر فعالية التي تتحكم في وفرة ونوزيع مجمو عات الأعشاب خلال موسم الصيف. 